\title{
Heavy metal contamination in the marine organisms in Yantai coast, northern Yellow Sea of China
}

\author{
Gaosheng Zhang $\cdot$ Dongyan Liu $\cdot$ Huifeng Wu \\ Linlin Chen · Qingxi Han
}

Accepted: 5 June 2012/Published online: 16 June 2012

(C) Springer Science+Business Media, LLC 2012

\begin{abstract}
The port city of Yantai, in Shandong province China is located on Sishili Bay in the northern Yellow Sea. Intense human activity associated with urban sewage discharge, as well as industrial and maritime activities, have stressed the Sishili Bay coastal ecosystem with anthropogenic pollution. The aim of this study was to measure the levels of heavy metal in the sediment and marine organisms of economic value from various sites within Sishili Bay, and to evaluate the data in relation to the potential health risk on human consumers. For this purpose, sediment and wild shrimps and crab were collected from three areas (a total of 13 sampling sites) of the Yantai coast and analyzed for six heavy metals $(\mathrm{Cu}, \mathrm{Zn}, \mathrm{Cr}, \mathrm{Ni}, \mathrm{Pb}$, and $\mathrm{As})$. For comparison, the concentrations of the same heavy metals in seven kinds of mollusks obtained from local aquaculture were also determined. The findings showed that the concentrations of heavy metals in the sediment of Yantai coast followed the order $\mathrm{Zn}>\approx \mathrm{Cr}>\mathrm{Cu} \approx$
\end{abstract}

G. Zhang · D. Liu $(\bowtie) \cdot H$. Wu $~$ L. Chen · Q. Han

Key Laboratory of Coastal Zone Environmental Processes, Yantai Institute of Coastal Zone Research (YIC),

Chinese Academy of Sciences (CAS), Shandong Provincial

Key Laboratory of Coastal Zone Environmental Processes,

YICCAS, Yantai 264003, Shandong, China

e-mail: dyliu@yic.ac.cn

G. Zhang

e-mail: gszhang@yic.ac.cn

H. Wu

e-mail: hfwu@yic.ac.cn

L. Chen

e-mail: 1lchen@yic.ac.cn

Q. Han

e-mail: qxhan@yic.ac.cn
$\mathrm{Ni} \approx \mathrm{Pb}>\mathrm{As}$, and all were within the safe levels of national standard. However, the concentrations of the heavy metals varied significantly in the organism samples, indicating the different accumulative abilities of the species sampled. For the wild marine organisms, $\mathrm{Pb}$ concentrations in some shrimp and crab samples exceeded the standard limit of seafood safety criteria and As concentrations in all samples were over the limit. Moreover, the As levels in mollusks from aquaculture exceeded the limit of seafood standard criteria. These results indicated that the heavy metal levels in the marine organisms in the studied areas were moderate but unacceptable for As from the view of safety of seafood. Furthermore, it is very necessary and important to further study toxicological and ecological effect of As in the coast of northern Yellow sea to understand the potential for risk to human and environmental health.

Keywords Heavy metals · Pollution - Marine environment $\cdot$ Seafood

\section{Introduction}

Heavy metal contamination in the marine environment has been highlighted by scientists and governments over the last decades, because their toxicity and accumulative behaviors in sediments and marine organisms can damage both marine species diversity and ecosystems (Matta et al. 1999; Roméo et al. 2005; Sivaperumal et al. 2007). Moreover, toxic heavy metals can accumulate in the body of marine organisms and transfer to human via the food chain and cause the potential health risk (Madany et al. 1996; Pourang and Dennis 2005; Firat et al. 2008). Thus, it is important to evaluate the heavy metal contents and 
Fig. 1 The sampling sites in Yantai coast and Sishili bay for collecting surface sediment and wild marine organisms

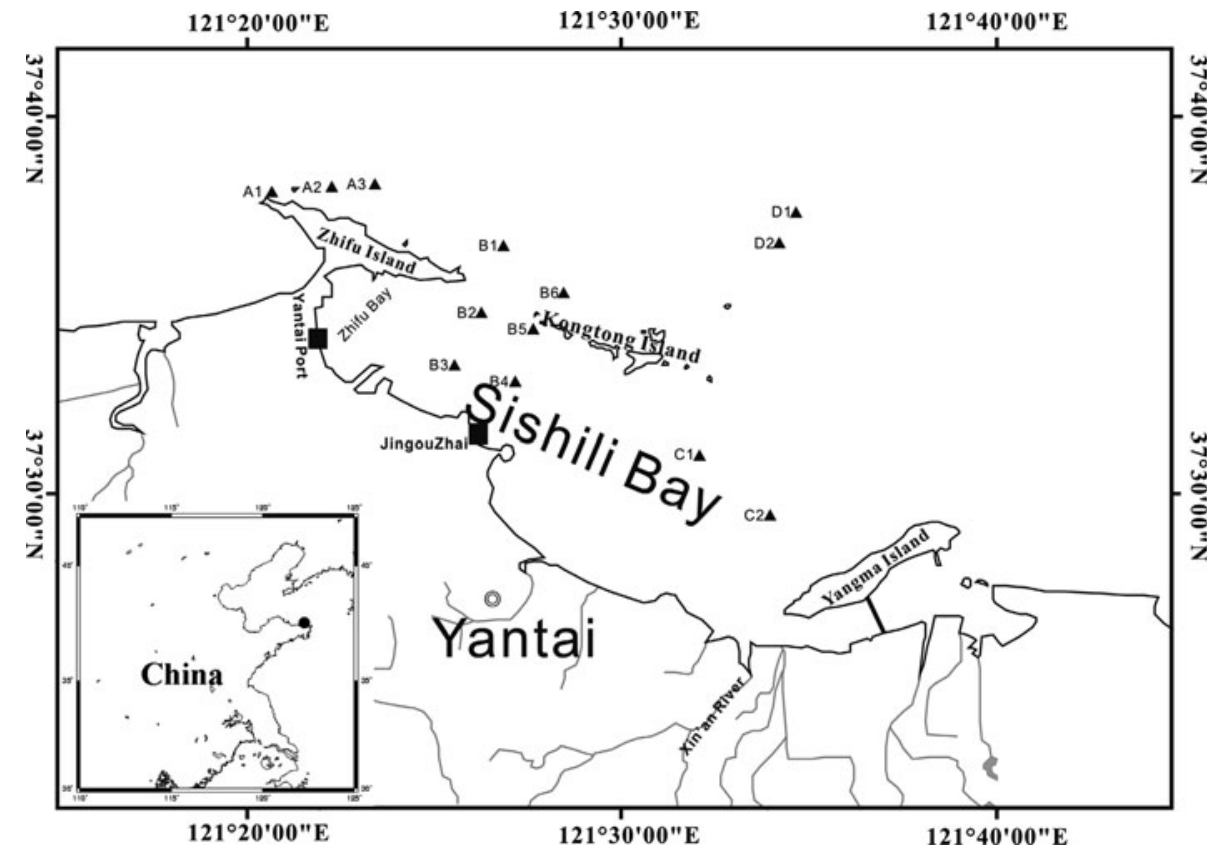

monitor their accumulations in the marine environment and organisms for seafood safety and the health of consumers.

Sishili Bay is located in the northern Yellow Sea, China, which is subject to the intense human activity from the surrounded city Yantai in Shandong province, China (Fig. 1). The increased population, urban sewage discharge and the shipment of Yantai Port have extremely stressed the coastal ecosystem (Wei et al. 2007; Yu et al. 2009). The anthropogenic inputs are considered as the important sources of heavy metals in marine environment, especially near the shoreline (Fung et al. 2004; María-Cervantes et al. 2009). However, few studies on the heavy metal contamination in marine environment and organisms have been carried out along the Yantai coastline, and the available information mainly focused on the mollusks obtained from the seafood markets (Wu et al. 2006; Wang et al. 2005). Thus, it is essential to evaluate the heavy metal contents in the marine environment and organisms along the Yantai coast for the seafood safety.

In this study, Sishili Bay, a typical marine aquaculture bay, was chosen as the study area. The variation of heavy metals in the surface sediment of the bay was studied to reflect the condition of marine environmental contamination, and the wild marine organisms were collected from the sea bottom for the analysis of the amounts of heavy metals in their tissue to understand the accumulation of heavy metal in wild marine organisms. Moreover, the main seafood from aquaculture was purchased from local seafood market to investigate the bioaccumulation of heavy metals, with a purpose of monitoring the seafood safety and comparing with the heavy metal level in the wild marine organisms.

\section{Materials and methods}

Sediments sampling and analysis

Surface sediments were collected from 13 sampling sites in the Sishili Bay, northern Yellow Sea, China (Fig. 1). For comparing with the different marine environment, sampling sites were designed in the sewage outfall area (A1, A2, and $\mathrm{A} 3)$, Yantai port area (B1-B6), aquaculture area (C1 and $\mathrm{C} 2$ ) and less human activity area (D1 and D2 as the contrast area). Approximately, $1 \mathrm{~kg}$ of surface sediment was taken and put in a polyethylene bag from each sampling site. The samples were then transported to the laboratory, air-dried and sieved to $2 \mathrm{~mm}$ in order to remove coarse fragments. A portion of each sieved sample was ground into fine powder in a mortar. Heavy metal contents were analyzed in triplicate according to EPA method 3052 (USEPA 1996). The ground sediment (approx. $0.25 \mathrm{~g}$ ) sample was put in a polytetrafluoroethylene digest container, $9 \mathrm{~mL}$ of proanalysis $69 \% \mathrm{HNO}_{3}$ and $3 \mathrm{~mL}$ of proanalysis $40 \% \mathrm{HF}$ were added for digestion. The container was sealed, placed into a microwave oven, heated for $5 \mathrm{~min}$ to reach $180{ }^{\circ} \mathrm{C}$, then kept at this temperature for $10 \mathrm{~min}$ and finally allowed to be cooled down for $60 \mathrm{~min}$. The obtained solution was then filtered. Heavy metals were measured using an Agilent 7500 inductively coupled plasma-mass spectrometer (ICPMS) (Agilent Technologies Co. Ltd, USA). Accuracy of the method was also assessed using certified reference material (sediment GBW 07315(GSMS-2)). Recoveries of all elements in the reference sediment ranged from 85.2 to $110.9 \%$. Concentrations reported in this study were not corrected for recovery rates. 
Table 1 Seven mollusk species purchased from the seafood markets of Yantai

\begin{tabular}{llllllll}
\hline Species & $\begin{array}{l}\text { Meretrix } \\
\text { meretrix }\end{array}$ & $\begin{array}{l}\text { Chiamys } \\
\text { farrer }\end{array}$ & $\begin{array}{l}\text { Mytilus } \\
\text { edulis }\end{array}$ & $\begin{array}{l}\text { Scapharca } \\
\text { subcrenata }\end{array}$ & $\begin{array}{l}\text { Concha } \\
\text { Ostreae }\end{array}$ & $\begin{array}{l}\text { Sol } \\
\text { sricus }\end{array}$ & $\begin{array}{l}\text { Saxidomrs } \\
\text { purpuratus }\end{array}$ \\
\hline Abbreviation & Mer & Chi & Myt & Sca & Con & Sol & Sax \\
\hline
\end{tabular}

Marine organisms sampling and analysis

Two species of shrimps (Oratosquilla aratoria and Alpheus distinguendus) and one species crab (Carcinoplax vestitus) samples were collected by net hauling from three locations (A: sewage outfall area, B: port area, and D: contrast area) in the Sishili Bay. For comparison, seven kinds of mollusks from the aquaculture in the bay were purchased from the local seafood markets of Yantai. The species of mollusks are listed in Table 1. The living samples were washed with seawater, placed in polyethylene bags and transported in an icebox.

After transported to laboratory, the marine organism samples were frozen. The animals were then dissected for the soft tissues which were homogenized in a blender, freeze-dried for 1 week, and eventually were ground into fine powder. The powder (Approx. $1 \mathrm{~g}$, accurately weighted) was weighed into a polytetrafluoroethylene digestion container. Ten milliliter of concentrated nitric acid was added to each sample and left to predigest overnight at $40{ }^{\circ} \mathrm{C}$. After cooling, $6 \mathrm{ml}$ of $30 \%$ hydrogen peroxide was added. Reagent blanks were processed simultaneously. Afterwards, the container was covered and placed in a stainless steel bomb, which was then sealed with a screw closure to avoid any acid leakage and placed in a microwave oven. The oven temperature was increased to $50{ }^{\circ} \mathrm{C}$ and kept for $1 \mathrm{~h}$ then increased to $160{ }^{\circ} \mathrm{C}$ for $4 \mathrm{~h}$. After cooling, the solution was transferred into a 50-mL PET bottle and diluted with Milli-Q water.

Concentrations of heavy metals $(\mathrm{Cu}, \mathrm{Zn}, \mathrm{Cr}, \mathrm{Ni}, \mathrm{Pb}$, and As) were measured by an ICP-MS (Agilent 7500i). All analyses were carried out in triplicate, using the external calibration method. Accuracy of the method was also assessed using Mussel 08571. Recoveries of all elements in Mussel 08571 ranged from 86.7 to $112.4 \%$. Concentrations reported in this study were not corrected for recovery rates.

\section{Results and discussion}

Heavy metal levels in sediment of the bay

The heavy metal contents in the sediments can indicate the contamination level of the water body related. The results of 13 sediment samples are shown in Fig. 2.
Generally, the concentrations of metals in the sediments followed the decreasing order $\mathrm{Zn}>\approx \mathrm{Cr}>\mathrm{Cu} \approx \mathrm{Ni} \approx$ $\mathrm{Pb}>$ As. According to zone, the mean concentrations of metals were in order: sewage outfall area $>$ Yantai port area $>$ contrast area $>$ aquaculture area. In the sewage outfall area, the heavy metal contents of the sediment in A1 site are the highest, which are obviously higher than the other two sites. $\mathrm{Zn}, \mathrm{Cr}, \mathrm{Cu}, \mathrm{Ni}, \mathrm{Pb}$, and As concentrations are $135.4,85.7,55.3,41.8,47.6$, and $19.1 \mathrm{mg} / \mathrm{kg}$ d.w., respectively. In the port area, the concentrations of metals at $\mathrm{B} 1$ and $\mathrm{B} 6$ sites are relatively higher than these at B2, B3, B4, and B5 sites. The average metal concentrations from the Yantai port area are 80.8, 71.8, 25.9, 28.9, 29.2, and $11.5 \mathrm{mg} / \mathrm{kg}$ d.w. for $\mathrm{Zn}, \mathrm{Cr}, \mathrm{Cu}, \mathrm{Ni}, \mathrm{Pb}$, and $\mathrm{As}$, respectively. The metal levels at D1 and D2 located in the contrast area are almost the same. The mean concentrations for these metals from the contrast area are 78.1, 71.0, 23.0, 30.6, 26.9, and $11.5 \mathrm{mg} / \mathrm{kg}$ d.w., respectively. Whereas, the sediment samples from the aquaculture area showed the lowest metal contents, particularly at site $\mathrm{C} 1$, the $\mathrm{Zn}, \mathrm{Cr}$, $\mathrm{Cu}, \mathrm{Ni}, \mathrm{Pb}$, and $\mathrm{As}$ concentrations are 63.6, 69.8, 18.4, $25.2,26.2$, and $8.6 \mathrm{mg} / \mathrm{kg}$ d.w., respectively.

The A1, A2, and A3 sampling sites are located in the sewage outfall, and site A1 is just close to the effluent outlet of the wastewater treatment plant, which may be responsible for the high metal levels in this area. The discharged effluent could diffuse from site A1 to B1, even impact the site D1and D2 with the sea current. This might be the reason that the heavy metal contents at these three sites are slightly higher than other sites except for the A1, $\mathrm{A} 2$, and $\mathrm{A} 3$. The activities of shipment may be the source of relatively higher heavy metals level in the port area. In contrast, the less industrial activities and shipment in aquaculture area showed lower levels of heavy metals.

Generally, the contamination of heavy metals in the Sishili Bay is light. According to the Chinese marine sediment quality criteria (National Standard of PR China 2002), all the metal contents in all samples are below the standard of first-class quality except for the $\mathrm{Cu}, \mathrm{Cr}$, and $\mathrm{Ni}$ at A1 site, which is slightly above the first-class limit and but not over the second-class standard.

Heavy metal levels in wild marine organisms

Heavy metal contents in the shrimp and crab which were collected from three zones by net hauling were analyzed 

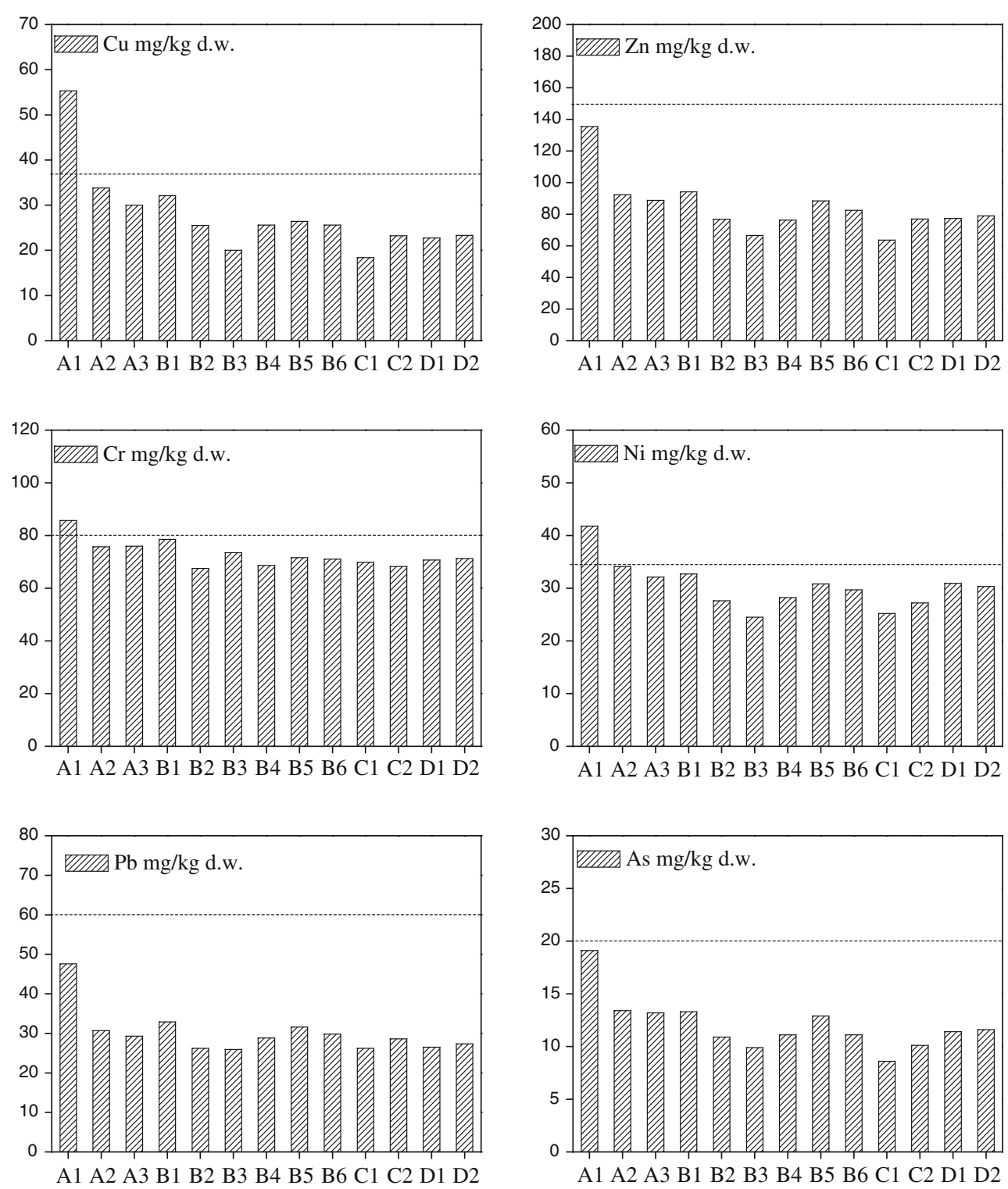

Fig. 2 Heavy metal contents in sediment samples of the Sishili Bay (Unit: milligrams per kilogram dry weight, dash lines using to compare the national criteria of good marine sediment quality)

and the results are illustrated in Fig. 3. The heavy metal levels in the shrimp and crab samples were in order: $\mathrm{Cu}>\mathrm{Zn}>\mathrm{As}>\mathrm{Ni}>\mathrm{Cr}>\approx \mathrm{Pb}$ and the contents ranged from 73.13 to $163.84,74.6$ to $97.09,14.11$ to $23.65,5.77$ to $23.13,1.55$ to 5.24 , and 1.82 to $4.95 \mathrm{mg} / \mathrm{kg}$ d.w., respectively. This suggested that the metal accumulative ability of the marine organism samples varied significantly, depending on the metal species. The metal accumulative abilities of the shrimp and crab followed the order $\mathrm{Cu}>\mathrm{Zn}>\mathrm{As}>\mathrm{Ni}>\mathrm{Cr}>\approx \mathrm{Pb}$. For the same heavy metal, its concentrations in different organism species did not vary significantly. For examples, $\mathrm{Zn}$ contents in the Oratosquilla aratoria, Alpheus distinguendus, and Carcinoplax vestitus from sewage outfall area were 94.45 ,
79.28, and $86.09 \mathrm{mg} / \mathrm{kg}$ d.w., respectively; $\mathrm{Pb}$ contents in these three species from the port area were 2.09, 2.25, and $2.88 \mathrm{mg} / \mathrm{kg}$ d.w., respectively. These data indicate that similar organism species have similar accumulative abilities towards the same heavy metal. For the view of the zone, the metal contents in the shrimp and crab samples collected from sewage outfall area are slightly higher than those from port area and contrast area. This is positively correlated with the results of metal contents from the surface sediment, to some extent, although the zone difference was not so significant as we expected.

Through the $\mathrm{Cu}$ and $\mathrm{Zn}$ concentrations in the organisms were high; they are in the range of national seafood safety standard (National Standard of PR China 2005). The Cr 

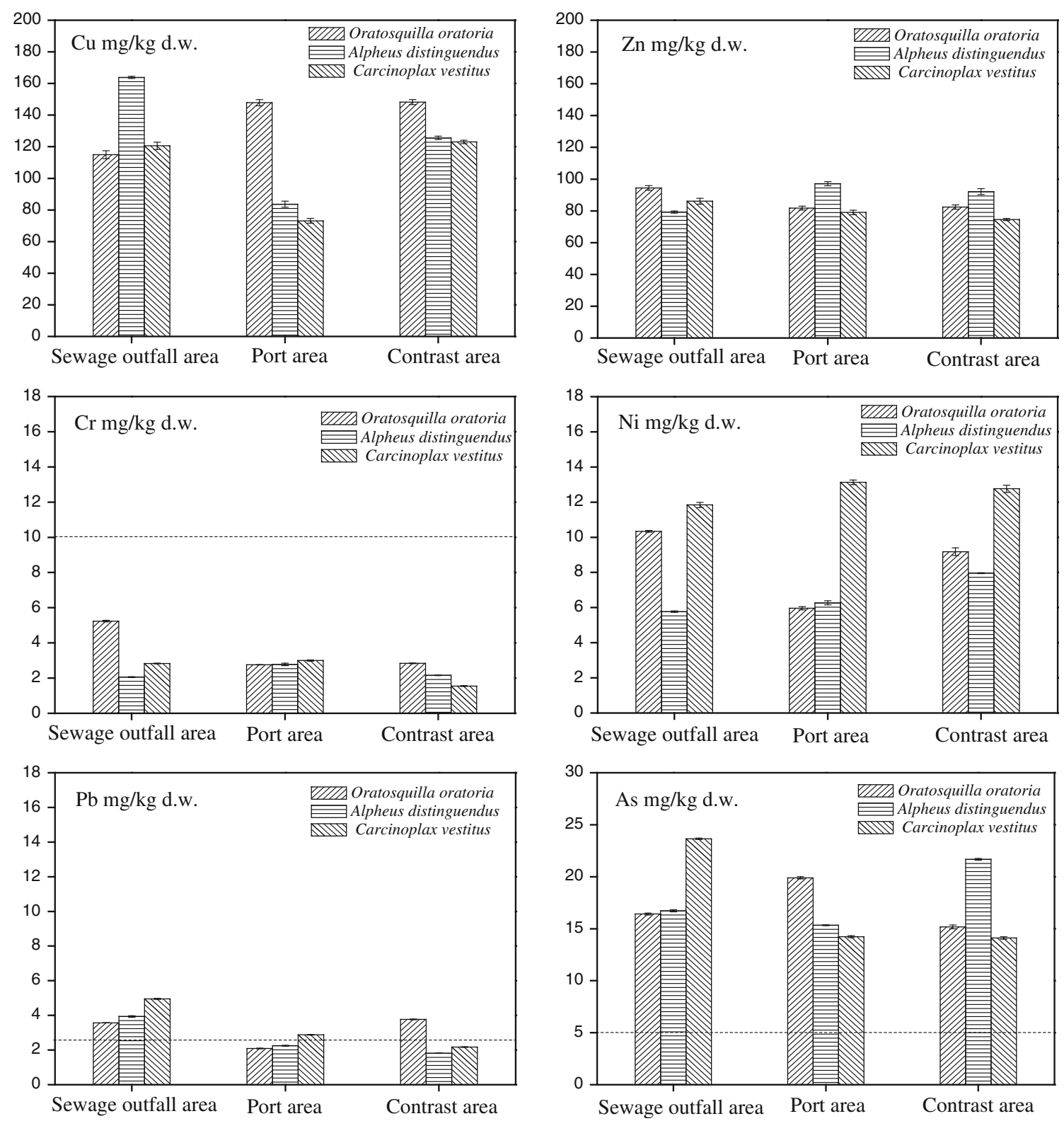

Fig. 3 Heavy metal contents in shrimp and crab samples collected from three sampling sites in the Sishili Bay (Unit: milligrams perkilogram dry weight, dash lines represent the national criteria of marine seafood safety for heavy metals)

levels in all samples are low as well meeting the safety criteria. $\mathrm{Pb}$ contents in some samples were a little high and exceeded slightly safety criteria. The As contents in the shrimp and crab are in the range of 14.11-23.65 mg/ kg d.w., which exceeded the seafood safety standard. As for $\mathrm{Ni}$, its levels in the shrimp and crab samples are relatively high and should be noted, although no related limit standard is given by national seafood safety.

Heavy metal levels in the mollusks from aquaculture

Concentrations of six metals $(\mathrm{Cu}, \mathrm{Zn}, \mathrm{Cr}, \mathrm{Ni}, \mathrm{Pb}$, and $\mathrm{As})$ in the mollusks collected from the Sishili Bay are demonstrated in Fig. 4. Obviously, the Zn contents in the mollusks were the highest $(66.6-494.4 \mathrm{mg} / \mathrm{kg}$ d.w.); Particularly in the Con and Chi $(F)$, the Zn contents reached to 494.4 and $445.5 \mathrm{mg} / \mathrm{kg}$ d.w., respectively, which indicate that the mollusks could have the high accumulative ability to the $\mathrm{Zn}$ element. The $\mathrm{Cu}$ contents in the organisms were not significant except for the species Con. with a value of $211.68 \mathrm{mg} / \mathrm{kg}$ d.w. which was much higher than the other species. The As concentrations were relatively higher than other metals with a range of 7.72$30.35 \mathrm{mg} / \mathrm{kg}$ d.w. The $\mathrm{Pb}$ and $\mathrm{Ni}$ concentrations were relatively lower, they ranged from 1.49 to 18.48 and 0.72 to $12.28 \mathrm{mg} / \mathrm{kg}$ d.w., respectively. The $\mathrm{Cr}$ contents in the 

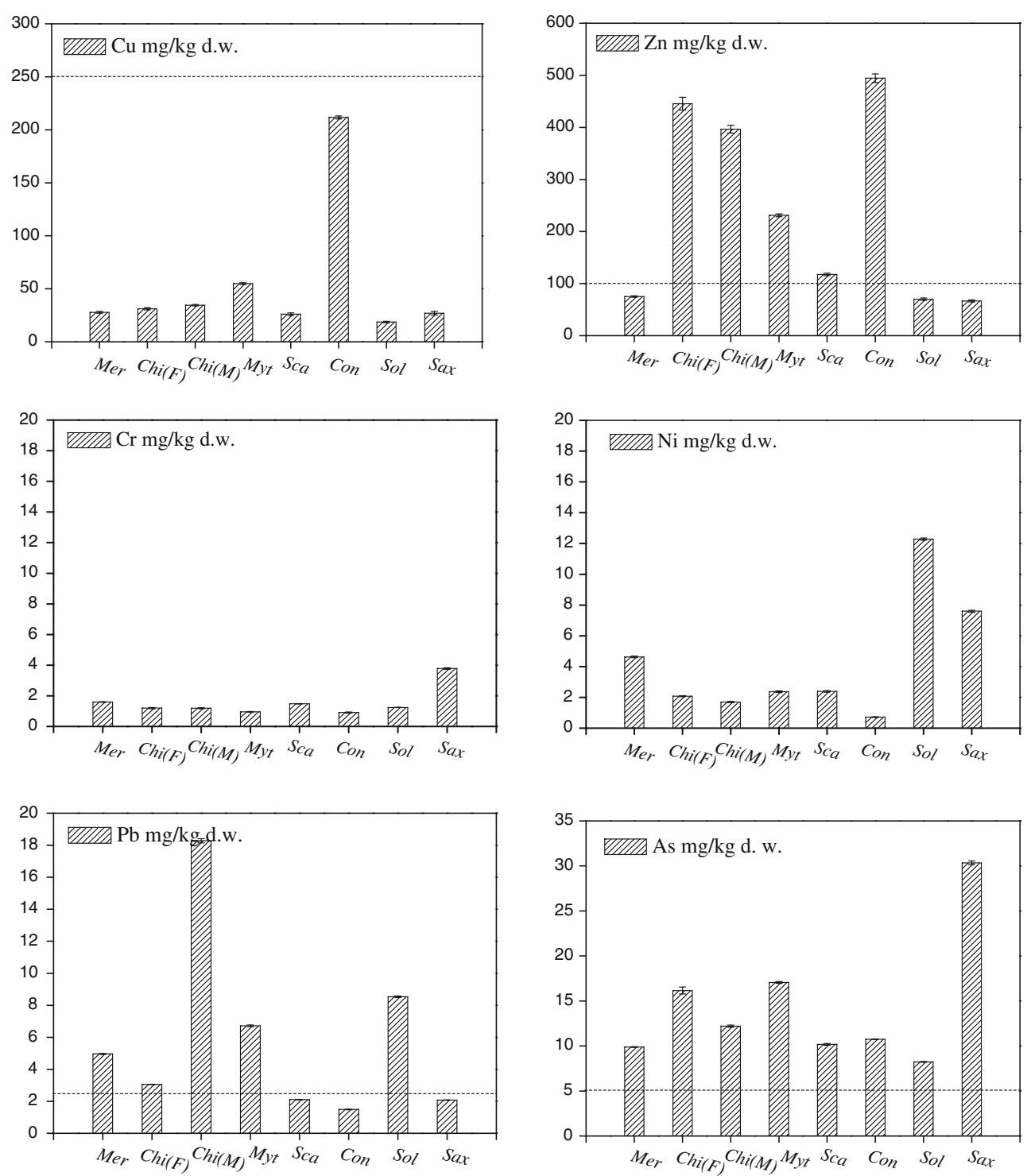

Fig. 4 Heavy metal contents in mollusks collected from seafood market of Yantai coast (Unit: milligrams perkilogram dry weight, $F$ (female) and $M$ (male) represent and the sex of mollusks, Dash lines represent the national criteria of marine seafood safety for heavy metals)

mollusks were the lowest, only in the range of $0.91-3.78 \mathrm{mg} / \mathrm{kg}$ d.w. Thus, the general order of heavy metal concentrations in the mollusks was $\mathrm{Zn}>\mathrm{Cu}>$ $\mathrm{As}>\mathrm{Ni}>\approx \mathrm{Pb}>\mathrm{Cr}$.

For the same heavy metal, its content in mollusks varied greatly from species to species. For example, $\mathrm{Cu}$ level in Sol was the lowest $(18.8 \mathrm{mg} / \mathrm{kg}$ d.w.), while in Con. was the highest $(211.7 \mathrm{mg} / \mathrm{kg} \mathrm{d.w.})$. Moreover, the same mollusk species displayed different metal accumulative ability. The Con. had a high accumulative ability towards $\mathrm{Zn}$ (494.4 mg/kg d.w.), whereas it had a very low accumulative ability to $\mathrm{Cr}(0.91 \mathrm{mg} / \mathrm{kg} \mathrm{d} . \mathrm{w})$. Additionally, the $\mathrm{Cu}$, $\mathrm{Zn}, \mathrm{Cr}, \mathrm{Ni}$, and As contents in $\mathrm{Chi}(F)$ were higher or equal to those in $\operatorname{Chi}(M)$. Interestingly, the $\mathrm{Pb}$ content in the $\operatorname{Chi}(M)$ was significantly higher than that in the $\operatorname{Chi}(F)$.
This indicates that the $\operatorname{Chi}(M)$ could have very high accumulative ability towards the $\mathrm{Pb}$.

To assess the current situation of metal contamination in marine organisms from Yantai coastal area, we compared the heavy metal contents in Con and Myt in this study with other reports from the northern Yellow Sea (Table 2). We found the metal concentrations in the Con in this study did not differ greatly from those reported by Liang et al. (2004). In the case of Myt collected from different sampling area and time (Table 3), the metal contents varied markedly. In general, the metal levels in the Con and Myt from the Yantai coastal area were not very high and the contamination was moderate.

From the view of seafood safety, the $\mathrm{Cu}$ levels in the mollusks were acceptable. The Zn levels in the Chi, Myt, 
Table 2 Comparison of heavy metal contents in Concha Ostreae from other areas of the Northern Yellow Sea

\begin{tabular}{|c|c|c|c|c|c|c|}
\hline Sampling time & Sampling site & $\mathrm{Ni}$ & $\mathrm{Pb}$ & $\mathrm{Zn}$ & $\mathrm{Cu}$ & Ref. \\
\hline 2009.07 & Sishili Bay ${ }^{\mathrm{a}}$ & 0.14 & 0.30 & 98.88 & 42.34 & Present study \\
\hline 2002.07-08 & Weihai & 0.11 & 0.21 & $135.40^{\mathrm{a}}$ & $27.31^{\mathrm{a}}$ & Liang et al. (2004) \\
\hline 2002.07-08 & Penglai & 0.44 & 0.46 & $115.95^{\mathrm{a}}$ & $60.75^{\mathrm{a}}$ & Liang et al. (2004) \\
\hline $2002.07-08$ & Qinhuangdao & 0.30 & 0.30 & $142.35^{\mathrm{a}}$ & $109.60^{\mathrm{a}}$ & Liang et al. (2004) \\
\hline 2002.07-08 & Tanggu & 0.18 & 0.22 & $181.40^{\mathrm{a}}$ & $25.24^{\mathrm{a}}$ & Liang et al. (2004) \\
\hline 2002.07-08 & Dalin & 0.22 & 0.62 & $379.55^{\mathrm{a}}$ & $31.32^{\mathrm{a}}$ & Liang et al. (2004) \\
\hline
\end{tabular}

a The values have been converted to wet weight contents (calculated as $80 \%$ water content)

Table 3 Comparison of heavy metal contents in Mytilus edulis from other areas of the Northern Yellow Sea

\begin{tabular}{|c|c|c|c|c|c|c|c|c|}
\hline Sampling time & Sampling site & $\mathrm{Cr}$ & $\mathrm{Ni}$ & $\mathrm{Pb}$ & $\mathrm{Zn}$ & $\mathrm{Cu}$ & As & Ref. \\
\hline 2009.7 & Sishili Bay ${ }^{\mathrm{a}}$ & 0.19 & 0.474 & 1.34 & 46.22 & 10.98 & 3.41 & Present study \\
\hline 1990 & Bohai Sea & & & 0.05 & 7.20 & 0.48 & & He (1996) \\
\hline 1990 & Yellow Sea & & & 0.81 & 89.8 & 2.30 & & He (1996) \\
\hline 1994 & Dalian Bay $^{\mathrm{a}}$ & & 0.18 & 0.59 & 50.60 & 4.54 & & Liu et al. (1995) \\
\hline 1994 & Xinghai Bay ${ }^{\mathrm{a}}$ & & & 0.64 & 49.60 & 2.32 & & Liu et al. (1995) \\
\hline 2001.9-10 & Dalian & & 1.50 & 0.51 & 76.89 & 1.83 & 12.7 & Fung et al. (2004) \\
\hline 2001.9-10 & Qingdao & 2.18 & 3.31 & 0.90 & 104.9 & 22.08 & 9 & Fung et al. (2004) \\
\hline 2002.07-08 & Weihai & 10.93 & 0.25 & 0.22 & 16.49 & 2.52 & 13.5 & Liang et al. (2004) \\
\hline 2002.07-08 & Penglai & & 0.23 & 0.60 & 22.42 & 2.07 & 0 & Liang et al. (2004) \\
\hline 2002.07-08 & Qinhuangdao & & 0.25 & 0.25 & 13.65 & 1.19 & 12.9 & Liang et al. (2004) \\
\hline 2002.07-08 & Yingkou & & 0.19 & 0.22 & 12.69 & 1.16 & 3 & Liang et al. (2004) \\
\hline 2002.07-08 & Dalin & & 0.18 & 0.16 & 11.87 & 1.14 & & Liang et al. (2004) \\
\hline 2002.07-08 & Bohai Sea & & $0.18-0.25$ & $0.16-2.52$ & $11.87-22.42$ & $1.16-2.52$ & & Liang et al. (2004) \\
\hline
\end{tabular}

a The values have been converted to wet weight contents (calculated as $80 \%$ water content)

and Con exceeded greatly the criteria of safety standard and $S c a$ was slightly over the criteria. The $\mathrm{Pb}$ levels in the Mer, Chi, Myt and Sol exceeded obviously the criteria. The total As levels in all seven mollusk species were above the seafood safety standard. In fact, the same phenomenon was observed in the wild shrimp and crab samples collected by net hauling. Our results indicate that As pollution in marine organisms in this area could be a problem in future if the pollution can not be controlled well, in spite that its concentrations in the sediment were not high during our survey. Thus, to some extent, the consumption of the shrimp, crab and mollusk from this area may have a potential risk for human health. However, the toxicity of organic arsenic is greatly lower than the inorganic and some literature reported that most of the As occurred as organic species in the marine organisms (Schaeffer et al. 2005; Borak and Hosgood 2007). Therefore, the determination of As species in the above organisms should be made in the further study.

\section{Conclusions}

The contamination of heavy metal in sediment in the Sishili Bay is not serious. The heavy metal concentrations in the sediment samples collected from the sewage outfall area were relatively higher. Sewage discharge may be the main cause for the higher concentrations.

The metal contents in shrimp and crab samples collected from three areas did not differ greatly, a little higher at sewage outfall area. $\mathrm{Pb}$ concentrations in some shrimp and crab samples exceeded the limit of seafood safety. In the case of As, all samples were over the limit. The levels of heavy metals in the mollusks purchased from the seafood market of Yantai varied greatly, depending on the metal species and organism species. The mollusks had high accumulative abilities towards the $\mathrm{Zn}$ and As. The concentrations of $\mathrm{Zn}$ and As were much above the limit of seafood standard. To some extent, the consumption of the shrimp, crab and mollusk from this area may have a 
potential risk for human health. However, the determination of As species in the above organisms should be made in the further study.

Acknowledgments This research was financially supported by the Innovative Program of the Chinese Academy of Sciences (KZCX2YW-Q07-04) and the Program of Frontier Field of Yantai Institute of Coastal Zone Research (HK0810AC-046).

\section{References}

Borak J, Hosgood HD (2007) Seafood arsenic: implications for human risk assessment. Regul Toxicol Pharmacol 47(2):204-212

Firat Ö, Gök G, Çoğun HY, Yüzereroğlu TA, Kargin F (2008) Concentrations of $\mathrm{Cr}, \mathrm{Cd}, \mathrm{Cu}, \mathrm{Zn}$ and $\mathrm{Fe}$ in crab Charybdis longicollis and shrimp Penaeus semisulcatus from the Iskenderun Bay, Turkey. Environ Monit Assess 147:117-123

Fung CN, Lam JCW, Zheng GJ, Connell DW, Monirith I, Tanabe S, Richardsona BJ, Lam PKS (2004) Mussel-based monitoring of trace metal and organic contaminants along the east coast of China using Perna viridis and Mytilus edulis. Environ Pollut 127:203-216

He GK (1996) Levels of heavy metals in mollusks from the coastal region of Bohai Sea and Huanghai Sea. China Environ Sci 16(2):96-100

Liang LN, He B, Jiang GB, Chen DY, Yao ZW (2004) Evaluation of mollusks as biomonitors to investigate heavy metal contaminations along the Chinese Bohai Sea. Sci Total Environ 324: $105-113$

Liu FC, Zhao YK, Chen LS, He ZL, Zhao GL (1995) Investigation and determination of 25 elements in mussels, kelps and undarias from Dalian Bay and Xinghai Bay Areas. Mar Environ Sci 14(4):34-38

Madany IM, Wahab AAA, Al-Alawi Z (1996) Trace metals concentrations in marine organisms from the coastal areas of Bahrain, Arabian Gulf. Water Air Soil Pollut 91:233-248

María-Cervantes A, Jiménez-Cárceles FJ, Álvarez-Rogel J (2009) As, $\mathrm{Cd}, \mathrm{Cu}, \mathrm{Mn}, \mathrm{Pb}$, and $\mathrm{Zn}$ Contents in sediments and mollusks (Hexaplex trunculus and Tapes decussatus) from Coastal Zones of a Mediterranean Lagoon (Mar Menor, SE Spain) affected by mining wastes. Water Air Soil Pollut 200:289-304
Matta J, Milad M, Manger R, Tosteson T (1999) Heavy metals, lipid peroxidation, and cigateratoxicity in the liver of the Caribben barracuda (Sphyraena barracuda). Biol Trace Elem Res 70:69-79

National Standard of PR China (2002) Marine sediment quality (GB 18668-2002). Standards Press of China, Beijing (in Chinese)

National Standard of PR China (2005) Food hygiene standards (GB 2005). Standards Press of China, Beijing (in Chinese)

Pourang N, Dennis JH (2005) Distribution of trace elements in tissues of two shrimp species from the Persian Gulf and roles of metallothionein in their redistribution. Environ Int 31:325-341

Roméo M, Frasila C, Gnassia-Barelli M, Damiens G, Micu D, Mustata G (2005) Biomonitoring of trace metals in the Black Sea (Romania) using mussels Mytilus galloprovincialis. Water Res 39:596-604

Schaeffer R, Soeroes C, Ipolyi I, Fodor P, Thomaidis NS (2005) Determination of arsenic species in seafood samples from the Aegean Sea by liquid chromatography-(photo-oxidation)hydride generation-atomic fluorescence spectrometry. Anal Chim Acta 547:109-118

Sivaperumal P, Sankar TV, Viswanathan Nair PG (2007) Heavy metal concentrations in fish, shellfish and fish products from internal markets of India vis-a-vis international standards. Food Chem 102:612-620

United States Environmental Protection Agency (USEPA) Method 3052 (1996) Microwave assisted acid digestion of siliceous and organically based matrices. USEPA, Washington, DC

Wang YW, Liang LN, Shi JB, Jiang GB (2005) Study on the contamination of heavy metals and their correlations in mollusks collected from coastal sites along the Chinese Bohai Sea. Environ Int 31:1103-1113

Wei EH, Sun YL, Wang C, Fu H (2007) The prediction of water quality on adjacent sea area after expansion work of sewage plant in Taozi Bay, Yantai. Chin Trans Oenol Limnol Suppl 164-169

Wu JZ, Yu XL, Bao P, Zhu LH (2006) Records of heavy metals in the sediments of Zhifu Bay in recent years. Period Ocean University China 36(1):141-144

Yu L, Hao YJ, Cai YY (2009) Annual variation of nutrient and Chla during HABs' periods in Sishili Bay. Chin Mar Environ Sci 28(5):558-561 